\title{
СВІТОВИЙ ДОСВІД БОРОТЬБИ 3 ВЕЙПІНГОМ ТА ЙОГО НАСЛІДКАМИ СЕРЕД ДІТЕЙ ТА МОЛОДІ
}

\section{Світовий досвід боротьби з вейпінгом та його наслідками серед дітей та молоді

\author{
л. І. Добровольська, О. Р. Боярчук, Т. В. Гаріян,
} К. Т. Глушко \\ Тернопільський національний медичний університет імені І. Я. Горбачевського МОЗ України}

Резюме. Використання електронних сигарет (вейпу) стрімко зростає в усьому світі. Поширення вживання е-сигарет відрізняється залежно від країни і по-різному контролюється державами. Все більша кількість наукових праць спрямована на вивчення наслідків вейпінгу. Найбільш поширеним виявилося специфрічне ускладнення у споживачів е-сигарет - ураження легень, пов'язане із вживанням вейпінг-продуктів (EVALI). Триває активне вивчення механізмів розвитку цього захворювання. Доведена ключова роль ацетату вітаміну Е у розвитку вказаної патології. Хоча на сьогодні етіологія відома, однак патогенез залишається до кінця не вивченим, особливо в умовах пандемії COVID-19.

Мета дослідження - проаналізувати літературні дані щодо поширення вейпінгу та його наслідків в усьому світі й Україні зокрема, визначити загрози для здоров'я дітей та молодих людей.

Матеріали і методи. У дослідженні опрацьовано наукові публікації за останні роки, які доступні у мережі «/нтернет», ключовими словами були «вейпінг», «е-сигаретu», «EVALI».

Результати. Дані, оприлюднені в 2017 р., показують, що в Україні 18,4 \% молодих людей віком від 13 до 15 років (22,6\% хлопців та $14 \%$ дівчат) є теперішніми споживачами електронних сигарет, а більш як $40 \%$ молодих людей мають досвід їх вживання. За даними Національного опитування молоді щодо тютюнових виробів у США використання е-сигарет щороку зростає, незважаючи на законодавчо врегульований обіг вейп-продуктів. Разом з тим, станом на 18 лютого 2020 р. у США було підтверджено 68 смертей унаслідок EVALI. Середній вік померлих пацієнтів складав від 15 до 75 років. Встановлено, що в умовах пандемії COVID-19 курці в 1,4 раза частіше мають важкі симптоми коронавірусної інфрекції і приблизно в 2,4 раза часmіше потрапляють до відділень інтенсивної терапії. Це викликає суттєве занепокоєння, враховуючи швидке поширення вейпінгу та його наслідків серед підлітків та молодих людей в усьому світі, а також і Україні.

Висновки. На сьогоднішні існують серйозні медичні ризики за умов вживання е-сигарет. Спалах EVALI
World experience of fight against vaping and its consequences among children and youth

\author{
L. I. Dobrovolska, O. R. Boyarchuk, T. V. Hariyan, \\ K. T. Hlushko
}

I. Horbachevsky Ternopil National Medical University e-mail: dobrovolska_li@tdmu.edu.ua

Summary. The using e-cigarettes (vape products) has been increasing rapidly. The prevalence of e-cigarette used varies around the world and is differently controlled at the governments level. Many scientific researches are aimed at studying the effects of vaping. E-cigarette, or vaping, product use associated lung injury (EVALI) is the most common specific complication in e-cigarette users. Studies are currently in progress of the mechanisms of development of this disease. The key role of vitamin $E$ acetate has been proven in the development of this pathology. Although the etiology is known today but the pathogenesis remains unexplored, especially in the context of the COVID-19 pandemic.

The aim of the study - to analyze the literature on the spread of vaping and its consequences around the world and in Ukraine in particular, to identify threat of the health in children and young people.

Materials and Methods. The study examines scientific publications in recent years, which are available on the Internet. The key words were "vaping", "e-cigarettes", "EVALI".

Results. The data published in 2017 showed that $18.4 \%$ of young people aged 13 to 15 (22.6\% of boys and $14 \%$ of girls) in Ukraine are currently using of e-cigarettes and more than $40 \%$ of young people have experience using them. According to National Youth Tobacco Survey data the use of e-cigarettes is growing every year despite the statutory circulation of vaping products in the United States. However, as of February 18, 2020, 68 deaths due to EVALI have been confirmed in the United States. The average age of deceased patients ranges 15 to 75 years. It has been found that in a COVID-19 pandemic, smokers are 1.4 times more likely to have severe symptoms of coronavirus infection and approximately 2.4 times more likely to be admitted to an intensive care unit. This is a matter of considerable concern, therefore, that the rapid spread of vaping and its consequences among adolescents and young people around the world, as well as in Ukraine.

Conclusions. There are serious medical risks with the use of e-cigarettes to date. The flash of EVALI emphasizes 
підкреслює необхідність регулювання вейп-продукції, що, на жаль, відсутнє в Україні. Це викликає суттєвє занепокоєння.

Ключові слова: вейпінг; е-сигарети; EVALI; діти; молодь.

\section{ВСТУП}

Тютюнокуріння має майже 500-річну історію і проблема його залишається актуальною і сьогодні. За даними ВОО3, вживання тютюну (активне і пасивне) щороку спричиняє загибель понад 8 млн людей у всьому світі [1]. В Європейському Союзі (€C) майже 0,7 млн смертей на рік пов'язані з вживанням тютюну. Серед дитячого населання Європейського регіону, за даними ВООЗ, 1 з 7 хлопчиків та 1 з 8 дівчаток у віці від 13 до 15 років споживають той чи інший продукт тютюну. Загалом, 3,9 млн підлітків є споживачами тютюнових виробів [2].

Для протидії глобальній тютюновій епідемії ВООЗ ініціювала розробку і прийняття Рамкової конвенції із боротьби проти тютюну (РКБТ) - першого у світі Міжнародного правового договору в сорері громадського здоров'я, який є обов'язковим для виконання. Рамкова конвенція із боротьби проти тютюну ратифрікована і в Україні Законом України від 15.03.2006 р. № 3534-IV. Офріційно вона набула чинності для України 04.09.2006 р. РКБТ містить перелік заходів, покликаних зменшити руйнівний вплив тютюну на здоров'я та економіку [3].

Результатом цієї боротьби стала позитивна динаміка тютюнокуріння серед дорослого і дитячого населення у всьому світі $[4,5]$.

Зокрема, в Україні знизилась не тільки поширеність вживання тютюну $326 \%$ у 2005 р. до 14,9 \% у 2017 р., а й суттєво зменшилася кількість тих, хто зазнав шкоди тютюнового диму в громадських місцях, підвищилась обізнаність молоді про шкідливість куріння [6, 7].

Поширеність куріння серед молоді (13-15 років), що визначалася в 2017 р., зменшилася на 23 \% порівняно 32011 р., та на 43 \% порівняно 32005 р. Проте досі вживають тютюнові вироби 14,9 \% підлітків (17,8 \% хлопців і 12,1\% дівчат) [6-8].

Поряд зі зниженням тютюнокуріння в усьому світі зростає проблема використання нетрадиційних тютюнових виробів як замінників звичайної цигарки. На сьогодні тютюнокуріння все частіше замінюють нагрітими тютюновими виробами (heated tobacco products -HTPS), електронними системами для доставки нікотину (electronic nicotine delivery systems-ENDS) та безнікотиновими електронними системами (electronic non-nicotine delivery systemsENNDS), що зазвичай називають «е-сигарети електронні сигарети».

Метою дослідження було проаналізувати літературні дані щодо поширення вейпінгу, його на- the need to regulate vaping products, which, unfortunately, is not available in Ukraine. This is a matter of considerable concern.

Key words: vaping; e-cigarettes; EVALI; children; youth.

слідків в усьому світі та Україні зокрема, визначити загрози для здоров'я дітей та молодих людей.

\section{МАТЕРІАЛИ I МЕТОДИ}

У дослідженні опрацьовано наукові публікації за останні роки, які доступні у мережі «нтернет», ключовими словами були «вейпінг», «е-сигарети», «EVALI».

\section{РЕЗУЛЬТАТИ Й ОБГОВОРЕННЯ}

Е-сигарети - це електронні пристрої, які генерують пар для вдихання шляхом нагріву спеціальної рідини (е-рідина), що містить нікотин, канабіас, інші ароматичні речовини та розчинник. Процес використання е-сигарет чи подібного пристрою називають вейпінгом (від англ. «vaping» - «куріння пари», «паріння).

Е-сигарети з'явилися і зайшли на світовий ринок у 2000-х роках. За даними досліджень, вживання е-сигарет найбільш поширене серед молоді у таких країнах як США, Канада та Англія [9].

32014 р. е-сигарети залишаються найпоширенішим тютюновим продуктом серед молоді США [9, 10]. Упродовж 2017-2018 рр. вживання е-сигарет збільшилось на 77,8 \% серед учнів старшої школи та на 48,5 \% серед учнів середньої школи [10, 11]. Кількість учнів середньої та старшої школи, які користуються е-сигаретами, зросла з 3,6 млн у 2018 р. до 5,4 млн в 2019 р. [12-15]. Використання е-сигарет протягом останніх 30 днів у 2019 р. вище, за результати спостережень Національного опитування молоді щодо тютюнових виробів у США (NYTS - National Youth Tobacco Survey) в 2018 p. [10, 11, 13, 14].

У різних провінціях Канади показники вживання е-сигарет серед молоді у 2016-2017 рр. відрізнялися: найнижчий - в Онтаріо, найвищий - у Новій Шотландії. 12,6 \% канадських учнів 7-9 класів повідомили, що деколи пробували е-сигарету. 5,4 \% використовували протягом останніх 30 днів. Серед канадців старше 15 років 15,4 \% дітей (4,6 млн) повідомили, що деколи пробували е-сигарету; 2,9 \% використали один раз за останні 30 днів і 1,0 \% зізналися у щоденному використанні [16].

32014 до 2017 р. частка європейців, які деколи пробували е-сигарету, зросла на 21 \% [2]. За даними досліджень, 2 \% громадян ЄС є постійними споживачами е-сигарет [2, 17].

Серед жителів Великої Британії у 2019 р. 15,4 \% дітей 11-18-річного віку спробували вейпінг порівняно 3 15,9 \% у 2018 р. Використання е-сигарет в 
Англії постійно збільшується, однак регулярне використання молодими людьми (11-18 років) залишається низьким $(1,7 \%)[18,19]$.

Хоча частота вживання е-сигарет в польській популяції порівняно низька, електронні сигарети набувають популярності серед підлітків та молодих людей [20-22]. Серед студентів у віці 15-19 років у Польщі поширеність вживання е-сигарет зросла 3 2 \% у 2010-2011 рр. до 11 \% у 2015-2016 рр. [20]. Згідно з опитуванням Eurobarometer 2017 р. 1,4% поляків були споживачами е-сигарет [2, 23].

У 2013 р. е-сигарети появилися і в Україні. Тому даних щодо поширення вейпінгу в Україні у звітах Глобального опитування молоді щодо вживання тютюну (GYTS) за 2005 та 2011 роки немає. Останні, проведені в Україні дослідження (GYTS 2017), показали, що 18,4 \% молодих людей віком від 13 до 15 років (22,6 \% хлопців та $14 \%$ дівчат) $€$ теперішніми споживачами електронних сигарет, а більш як 40 \% молодих людей мають досвід їх вживання [6].

Такі фракти викликають велике занепокоєння, враховуючи те, що порядок продажу е-сигарет в Україні не врегульований на законодавчому рівні. Тому неповнолітні в Україні мають вільний доступ до вейпінг-продуктів, на відміну від інших вищезгаданих країн. Так, мінімальний вік для використання е-сигарет в США та Канаді становить від 18 до 21 років (залежно від штату або провінції) [24].

У більшості європейських країнах діють ті ж самі обмеження, що й для тютюнових виробів: забороняється реклама та заборонений продаж е-сигарет дітям до 18 років та їх використання у закритих громадських приміщеннях.

Незважаючи на діючі обмеження щодо вживання е-сигарет підлітками та молодими людьми, у багатьох країнах світу вже існують відомості про потенційний розвиток залежності, збільшення частоти нападів астми та рефлекторного кашлю, гострої ендотеліальної дисфункції, тахікардії, зростання артеріального тиску та канцерогенез [25]. Виявляють різні види травм від застосування вейп-продуктів, такі, як вибухові травми, шкірні реакції, отруєння, тоді як найбільш поширеним залишається розвиток респіраторних симптомів [26, 27].

Починаючи з середини 2019 р., США стикнулися зі спалахом специфічного ускладнення у споживачів е-сигарет - ураженням легень, пов'язаним із вживанням е-сигарет або вейпінг-продуктів (e-cigarette, or vaping product use associated lung injury, EVALI) [28].

Станом на 8 жовтня 2019 р. з'явилося повідомлення про 1299 випадків EVALI. Серед 1043 пацієнтів, з наявними даними про вік і стать, 70 \% становили чоловіки, а середній вік - 24 роки (від 13 до 75 років). Зафріксовано 26 випадків смерті (се- редній вік смерті 49 років, з діапазоном від 17 до 75 років) [28]. Станом на 18 лютого 2020 р. Центрами контролю захворювань встановлено 2807 госпіталізованих пацієнтів із підтвердженим або ймовірним діагнозом EVALI у США [29], серед яких було 68 підтверджених смертей. Середній вік померлих пацієнтів становив 49,5 року з діапазоном від 15 до 75 років [29].

Найбільш критичним фрактором ризику розвитку EVALI залишається використання ENDSпродуктів протягом попередніх 90 днів. Однак часовий діапазон розвитку симптомів або помітних структурних змін залишається невідомим. Симптоми можуть розвиватися вже через кілька годин після вдихання до місяців після використання [29, 30].

EVALI - це діагноз виключення, що вимагає візуалізації легень (КТ та рентгенографрія органів грудної клітки), з підтвердженням двосторонніх змін - вогнищеві інфільтративні зміни в легенях, що межують із нормальною легеневою тканиною. Обов'язковим є виключення вірусних, бактеріальних, атипових збудників, а також іншої легеневої патології [30-32].

За даними Центру з контролю і профрілактики захворювань США (Centers for Disease Control and Prevention, CDC), Управління 3 санітарного нагляду за якістю харчових продуктів і медикаментів (Food and Drug Administration, FDA, USFDA) та ін. [32-34] EVALI може супроводжуватися дихальними симптомами (кашель, задишка або біль у грудній клітці); шлунково-кишковими симптоми (нудота, блювання, біль у шлунку або діарея); та неспецифічними симптомами (лихоманка, озноб або зниження маси тіла).

На сьогодні доведений зв'язок ацетату вітаміну E зі спалахом EVALI. Ацетат вітаміну E використовується як розріджувач у тетрагідроканабінолових картриджах е-сигарет [27, 29]. У вигляді вітамінної добавки ацетат вітаміну $\mathrm{E}$, як правило, не заподіює шкоди при прийомі його всередину або нанесення на шкіру. Однак попередні дослідження говорять про те, що при вдиханні ацетату вітаміну E, він може порушувати нормальну роботу легень [29]. Ацетат вітаміну E був знайдений у зразках продуктів, взятих FDA та державними лабораторіями США, і у зразках легеневої рідини пацієнтів, взятих CDC із географрічно різних штатів. Останній не був виявлений у легеневій рідині людей, у яких немає EVALI [35].

Пропіленгліколь і гліцерин - це речовини, які зволожують й утримують воду, а також при нагріванні в е-сигаретах утворюють легеневі канцерогенні карбонільні сполуки (формальдегід, ацетальдегід та акролеїн). Метали, що містяться в нагрівальних котушках і оболонках картриджа, можуть вилужувати метали, такі, як алюміній, хром, 
залізо, свинець, марганець, нікель і олово. Ароматизатори вважаються безпечними для прийому всередину, але відсутні дані про безпеку для інгаляційного шляху їх використання. Діацетил, звичайний масляний ароматизатор, відомий легеневою токсичністю при інгаляційному впливі, що призводить до облітерації бронхіол [27].

Тривалі спостереження показали, що нікотин знижує циліарний кліренс слизової оболонки дихальних шляхів, що призводить до накопичення надлишку слизу, який діє як резервуар для бактерій. Нікотин пригнічує або порушує багато аспектів імунної системи, зокрема знижує фрункції Т-клітин, макрофрагів та NK-клітин, тим самим послаблюючи противірусну відповідь і збільшує сприятливість до грипу [36, 37]. Так, в умовах пандемії COVID-19 китайські вчені встановили, що в курців у 1,4 раза частіше виникають тяжкі симптоми коронавірусної інфрекції і приблизно в 2,4 раза частіше потрапляють до відділення інтенсивної терапії, потребують механічної вентиляції або помирають порівняно $з$ тими, хто не курить [38].

Проведені дослідження продемонстрували також несприятливий вплив нікотину на розвиток головного мозку підлітків, що проявляється зниженням виконавчих фрункцій (робоча пам'ять, увага), здатності приймати рішення, якості сну, може спричинити розвиток депресії $[39,40]$. Це особливо актуально, оскільки деякі дослідження показують, що кількість нікотину в певних картриджах для е-сигарет може бути еквівалентною до 20 звичайних сигарет [41].

Попередні результати досліджень свідчать про те, що деякі підлітки використовують е-сигарети для випаровування канабісу у вигляді гашеної олії, тетрагідроканабінолу (ТГК) воску чи олії, або сушених бутонів або листя канабісу. Приблизно 1310 учнів середньої школи повідомляв про те, що колинебудь вепінгував канабіс [42]. Вживання ТГК було пов'язане з широким спектром впливу на здоров'я, особливо при тривалому інтенсивному вживанні. Ці ефекти варіюють від короткотривалих проблем з увагою, пам'яттю до довгострокових проблем, таких, як депресія, психоз, тривога, суїцидальні настрої [43-45].

\section{СПИСОК ЛІТЕРАТУРИ}

1. World Health Organization. Tobacco. WHO; Geneva, Switerland: 2019. [(accessed on 26 October 2019)]. [Electronic resource]. - Accees mode : https://www.who.int/ news-room/fact-sheets/detail/tobacco.

2. European Commission Special Eurobarometer 458 - Attitudes of Europeans towards Tobacco and Electronic Cigarettes. [(accessed on 16 October 2019)]; [Electronic resource]. - Accees mode : https://publications.europa. eu/en/publication-detail/-/publication/2f01a3d1-0af2-11e8966a-01aa75ed71a1/language-en.
На жаль, статистики щодо випадків EVALI в Україні немає. Однак враховуючи поширеність використання е-сигарет у світі та в нашій країні, наслідків їх вживання серед дитячого населення, провідні дитячі спеціалісти в складі робочої група Української Академії Педіатричних спеціальностей запропонували чіткі рекомендації для запобігання поширення і розвитку ускладнень вейпінгу [46]:

1. Продаж е-сигарет та вейпінг-продуктів повинен бути заборонений особам віком молодше 18 років, а продаж повнолітнім здійснюватися лише за наявності документа, який засвідчує вік.

2. Прирівняти е-сигарети, їх використання та рекламу до традиційних сигарет та внести відповідні доповнення у чинне законодавство України.

3. Рекомендація щодо припинення використання е-сигарет та вейпінг-продуктів не є закликом до повернення до куріння традиційних тютюнових виробів.

4. Вживання е-сигарет повнолітніми не повинне відбуватись у присутності дітей.

5. Вживання е-сигарет та вейпінг-продуктів повнолітніми потребує ретельного медичного контролю за станом здоров'я, особливо дихальної системи.

6. При виникненні симптомів респіраторного захворювання у людини 3 історією вживання е-сигарет та вейпінг-продуктів необхідно негайно звернутися до лікаря.

7. Кожний лікар, який працює з підлітками, а також вагітними жінками, повинен під час медичного консультування обговорювати ризики для здоров'я, що пов'язані з вживанням е-сигарет.

\section{ВИСНОВКИ}

Проведений аналіз літературних джерел свідчать про те, що сьогодні існують серйозні медичні ризики при вживанні е-сигарет. Значне зростання застосування е-сигарет серед молоді може знизити недавній прогрес у зменшенні загального споживання тютюнових виробів серед молоді. Спалах EVALI підкреслює необхідність регулювання вейп-продукції, що на сьогодні відсутнє в Україні. Ураження легень, асоційоване з вейп-продукцією, може мати фратальні наслідки в умовах пандемії COVID-19 та суттєво впливати на перебіг хвороби.

3. Рамкова конвенція ВООЗ із боротьби проти тютюну // Офіц. вісник України від 12.04.2006 р. - 2006. № 13. - С. 128 , стаття 861.

4. World Health Organization. (2018). WHO global report on trends in prevalence of tobacco smoking 20002025, 2nd ed. World Health Organization. - Access mode : https://apps.who.int/iris/handle/10665/272694.

5. GBD 2015 SDG Collaborators. Measuring the healthrelated Sustainable Development Goals in 188 countries: A baseline analysis from the Global Burden of Disease Study 
2015 / S. S. Lim, K. Allen, Z. A. Bhutta [et al.] // Lancet. 2016. - Vol. 388. - P. 1813-1850.

6. Ukraine GYTS 2005 Factsheet (Ages 13-15). Centers for Disease Control [Electronic resource]. - Access mode : https://extranet.who.int/ncdsmicrodata/index.php/ catalog/607. https://www.tobaccofreekids.org/assets/ global/pdfs/reports_articles/Ukraine_tob_burden_en.pdf

7. Ukraine GYTS 2017 Factsheet (Ages 13-15). Centers for Disease Control [Electronic resource]. - Access mode : https://extranet.who.int/ncdsmicrodata/index.php/ catalog/609/study-description. https://en.moz.gov.ua/ uploads/0/482-gyts_ukraine_2017_factsheet.pdf.

8. Ukraine GYTS 2011 Factsheet (Ages 13-15). Centers for Disease Control [Electronic resource]. - Access mode : https://extranet.who.int/ncdsmicrodata/index.php/ catalog/608/study-description. https://www.tobaccofreekids. org/assets/global/pdfs/en/Ukraine_GYTS_2011_Factsheet. pdf.

9. Prevalence of vaping and smoking among youth in Canada, England and the United States: repeat national cross-sectional surveys / D. Hammond, J. Reid, V. Rynard et al. // Br. Med. J. - 2019. - Vol. 365 - P. 12219.

10. Arrazola R. A. Tobacco product use among middle and high school students - United States, 2011 and 2012 I R. A. Arrazola, S. R. Dube, B. A. King // MMWR Morbidity and Mortality Weekly Report. - 2013. - Vol. 62 (45). P. 893-897.

11. Vital signs: tobacco product use among middle and high school students - United States, 2011-2018 / A. S. Gentzke, M. Creamer, K. A. Cullen [et al.] // MMWR Morbidity and Mortality Weekly Report. - 2019. - Vol. 68 (6). - P. 157-164.

12. Notes from the field: use of electronic cigarettes and any tobacco product among middle and high school students - United States, 2011-2018 / K. A. Cullen, B. K. Ambrose, A. S. Gentzke [et al.] // MMWR Morbidity and Mortality Weekly Report. - 2018. - Vol. 67 (45). P. 1276-1277.

13. E-cigarette use among youth in the United States, 2019 / K. A. Cullen, A. S. Gentzke, M. D. Sawdey [et al.] // JAMA. - 2019. - Vol. 322 (21). - 2095-2103.

14. Tobacco product use and associated factors among middle and high school students - United States, 2019 / T. W. Wang, A. S. Gentzke, M. R. Creamer [et al.] // MMWR Morbidity and Mortality Weekly Report. - 2019. - Vol. 68 (SS-12). - P. 1-22.

15. Tobacco product use among middle and high school students - United States, 2011-2018 / A. S. Gentzke, M. Creamer, K. A. Cullen [et al.] // MMWR Morbidity and Mortality Weekly Report. - 2018. - Vol. 67. - P. 629-633.

16. Tobacco Use in Canada: Patterns and Trends, 2019 Edition. Waterloo, ON: Propel Centre for Population Health Impact, University of Waterloo / J. L. Reid, D. Hammond, U. Tariq [et al.]. - [Electronic resource]. - Access mode : https://uwaterloo.ca/tobacco-use-canada/tobacco-usecanada-patterns-and-trends.

17. Laverty A. A. Patterns, trends and determinants of e-cigarette use in 28 European Union Member States 20142017 / A. A. Laverty, F. T. Filippidis, C. I. Vardavas // Prev. Med. - 2018. - Vol. 116. - P. 13-18.

18. Evidence Review of E-Cigarettes and Heated Tobacco Products 2018; A Report Commissioned by Public
Health England / A. McNeill, L. S. Brose, R. Calder [et al.] . Public Health England: London, UK, 2018 [(accessed 10 April 2019)]; [Electronic resource]. - Access mode : https://www.gov.uk/government/publications/e-cigarettesand-heated-tobacco-products-evidence-review/evidencereview-of-e-cigarettes-and-heated-tobacco-products2018-executive-summary.

19. Vaping in England, an evidence updates, February 2019. A report commissioned by Public Health England / A. McNeill, L. S. Brose, R. Calder [et al.]. - 2019. - London: Public Health England [Electronic resource]. - Access mode : https://assets.publishing.service.gov.uk/government/uploads/ system/uploads/attachment_data/file/821179/Vaping_in_ England_an_evidence_update_February_2019.pdf.

20. Exclusive versus dual use of tobacco and electronic cigarettes among adolescents in Poland, 2010-2016 / D. M. Smith, M. Gawron, L. Balwicki [et al.] // Addict. Behav. - 2019. - Vol. 90. - P. 341-348.

21. E-smoking among students of medicine-Frequency, pattern and motivations / G. Brożek, M. Jankowski, J. Zejda [et al.] // Adv. Respir. Med. - 2017. - Vol. 85 (1). - P. 8-14.

22. The Prevalence of Cigarette and E-cigarette Smoking Among Students in Central and Eastern Europe Results of the YUPESS Study / G. M. Brożek, M. Jankowski, J. A. Lawson [et al.] // Int. J. Environ. Res. Public Health. 2019. - Vol. 16 (13). - P. 2297.

23. The prevalence of tobacco and e-cigarette use in Poland: A 2019 Nationwide Cross-Sectional Survey / J. Pinkas, D. Kaleta, W. S. Zgliczyński [et al.] // Int. J. Environ. Res. Public Health. - 2019. - Vol. 16 (23). - P. 4820.

24. U.S. e-cigarette regulations - 50 state review (2020) [Electronic resource]. - Access mode : https:// www. publichealthlawcenter.org/sites/default/files/Stateswith-Laws-Restricting-Youth-Access-to-ECigarettesMarch152020.pdf.

25. National Academies of Sciences, Engineering, and Medicine; Health and Medicine Division; Board on Population Health and Public Health Practice / D. L. Eaton, L. Y. Kwan, K. Stratton [et al.], eds. // Public Health Consequences of E-Cigarettes. Washington (DC): National Academies Press (US) - January 23, 2018. - Access mode : https://doi.org/10.17226/24952.

26. US department of health and human services. e-cigarette use among youth and young adults: A report of the surgeon general. Atlanta, GA: US Department of Health and Human Services, CDC; 2016. [(accessed July 27, 2018)]; [Electronic resource]. - Access mode : https:// www.cdc.gov/tobacco/data_statistics/sgr/e-cigarettes/ pdfs/2016_sgr_entire_report_508.pdf.

27. Quick facts on the risks of e-cigarettes for kids, teens, and young adults centers for disease [Electronic resource]. - Access mode : https://www.cdc.gov/tobacco/ basic_information/e-cigarettes/Quick-Facts-on-the-Risksof-E-cigarettes-for-Kids-Teens-and-Young-Adults.html

28. Review of health consequences of electronic cigarettes and the outbreak of electronic cigarette, or vaping, product use-associated lung injury / D. J. Cao, K. Aldy, S. Hsu [et al.] // J. Med. Toxicol. - 2020. - Vol. 16 (3). - P. 295-310.

29. Outbreak of lung injury associated with the use of e-cigarette, or vaping, products. Center for Disease Control 
and Prevention. 2019. [(accessed 20 Feb 2020)]; [Electronic resource]. - Accees mode : https://www.cdc.gov/tobacco/ basic_information/e-cigarettes/severe-lung-disease.html.

30. Update: interim guidance for health care providers evaluating and caring for patients with suspected e-cigarette, or vaping, product use associated lung injury - United States, October 2019 / D. A. Siegel, T. C. Jatlaoui, E. H. Koumans [et al.] // MMWR Morbidity and Mortality Weekly Report. - 2019. - Vol. 68 (41). - P. 919-927.

31. E-cigarette, or vaping, product use-associated lung injury (EVALI): acute lung illness within hours of switching from traditional to e-cigarettes / S. Deliwala, S. Sundus, T. Haykal [et al.] // Cureus. - 2020. - Vol. 12 (4). - P. e7513.

32. Pulmonary illness related to e-cigarette use in illinois and wisconsin - final report / J. E. Layden, I. Ghinai, I. Pray [et al.] // N. Engl. J. Med. - 2020. - Vol. 382 (10). P. 903-916.

33. E-cigarette, or vaping, product use associated lung injury (EVALI): case series and diagnostic approach / A. Kalininskiy, C. T. Bach, N. E. Nacca [et al.] // Lancet Respir. Med. - 2019. - Vol. 7 (12). - P. 1017-1026.

34. Vaping-associated acute lung injury: a case series / G. A. Triantafyllou, P. J. Tiberio, R. H. Zou [et al.] // Am. J. Respir. Crit. Care Med. - 2019. - Vol. 200(11). - P. 14301431.

35. Vitamin E. Acetate in bronchoalveolar-lavage fluid associated with EVALI / B. C. Blount, M. P. Karwowski, P. G. Shields [et al.] // N. Engl. J. Med. - 2020. - Vol. 382 (8). - P. 697-705.

36. Impacts of cigarette smoking on immune responsiveness: up and down or upside down? / F. Qiu, C-L. Liang, H. Liu [et al.] // Oncotarget. - 2017. - Vol. 8 (1). - P. 268-284.

37. Cigarette smoke dampens antiviral signaling in small airway epithelial cells by disrupting TLR3 cleavage /

\section{REFERENCES}

1. World Health Organization. Tobacco. WHO; Geneva, Switerland: 2019. [(accessed on 26 October 2019)]. [Electronic resource]. Available from: https://www.who.int/ news-room/fact-sheets/detail/tobacco.

2. European Commission Special Eurobarometer 458 - Attitudes of Europeans towards Tobacco and Electronic Cigarettes. [(accessed on 16 October 2019)]; [Electronic resource]. Available from: https://publications.europa.eu/en/ publication-detail/-/publication/2f01a3d1-0af2-11e8-966a01aa75ed71a1/language-en.

3. [WHO Framework Convention on Tobacco Control]. Ofits visnyk Ukrainy. 2006;13:128, law article 861.4. Ukrainian.

4. World Health Organization. (2018). WHO global report on trends in prevalence of tobacco smoking 20002025, 2nd ed. World Health Organization. [Electronic resource]. Available from: https://apps.who.int/iris/ handle/10665/272694.

5. Lim SS, Allen K, Bhutta ZA, Dandona L, Forouzanfar $\mathrm{MH}$, Fullman N, et al. GBD 2015 SDG Collaborators. Measuring the health-related sustainable development goals in 188 countries: A baseline analysis from the global burden of disease study 2015. Lancet. 2016;388: 1813-50. Available from: https://doi.org/10.1016/S01406736(16)31467-2.
P. F. Duffney, C. E. McCarthy, A. Nogales [et al.] // Am. J. Physiol. Lung Cell Mol. Physiol. - 2018. - Vol. 314 (3). P. L505-L513.

38. Clinical characteristics of coronavirus disease 2019 in China / W. J. Guan, Z. Y. Ni, Y. Hu [et al.] // N. Engl. J. Med. - 2020. - Vol. 382. - P. 1708-1720

39. Neurotoxicity of e-cigarettes / J. A. Ruszkiewicz, Z. Zhang, F. M. Gonçalves [et al.] // Food Chem. Toxicol. 2020. - Vol. 138. - P. 111245.

40. Selekman J. Vaping: It'sallasmokescreen/J. Selekman// Pediatric Nursing. - 2019. - Vol. 45(1). - P. 12-15, 35.

41. Tobore T. O. On the potential harmful effects of E-Cigarettes (EC) on the developing brain: The relationship between vaping-induced oxidative stress and adolescent/ young adults social maladjustment / T. O. Tobore // J. Adolesc. - 2019. - Vol. 76. - P. 202-209.

42. Vaping cannabis among adolescents: prevalence and associations with tobacco use from a cross-sectional study in the USA/S. D. Kowitt, A. Osman, C. Meernik [et al.] // B. M. J. - 2019. - Vol. 9 (6). - P. e028535.

43. Adverse health effects of marijuana use / N. D. Volkow, R. D. Baler, W. M. Compton, S. R. B. Weiss // N. Engl. J. Med. - 2014. - Vol. 370 (23). - P. 2219-2227.

44. Cannabis and alcohol use, and the developing brain / A. D. Meruelo, N. Castro, C. I. Cota, S. F. Tapert // Behav. Brain Res. - 2017. - Vol. 325 (Pt A). - P. 44-50. DOI: 10.1016/j.bbr.2017.02.025.

45. Silins E. Young adult sequelae of adolescent cannabis use: An integrative analysis / E. Silins, L. J. Horwood, G. C. Patton // The Lancet Psychiatry. 2014. - Vol. 1 (4). - P. 286-293.

46. Щодо потенційної небезпеки використання електронних сигарет дітьми та підлітками / М. Маменко, І. Романкевич, Л. Раковська та ін. // Сучасна педіатрія. Україна. - 2019. - 8(104). - С. 6-8.

6. Ukraine GYTS 2005 Factsheet (Ages 13-15). Centers for Disease Control [Electronic resource]. Available from: https://extranet.who.int/ncdsmicrodata/index.php/ catalog/607

https://www.tobaccofreekids.org/assets/global/pdfs/ reports_articles/Ukraine_tob_burden_en.pdf.

7. Ukraine GYTS $20 \overline{17}$ Factsheet (Ages 13-15). Centers for Disease Control [Electronic resource]. Available from: https://extranet.who.int/ncdsmicrodata/index.php/ catalog/609/study-description

https://en.moz.gov.ua/uploads/0/482-gyts_ ukraine_2017_factsheet.pdf.

8. Ukraine GYTS 2011 Factsheet (Ages 13-15). Centers for Disease Control [Electronic resource]. Available from: https://extranet.who.int/ncdsmicrodata/index.php/ catalog/608/study-description

https://www.tobaccofreekids.org/assets/global/pdfs/en/ Ukraine GYTS 2011 Factsheet.pdf.

9. Hammond D, Reid J, Rynard V, Fong G, Cummings $\mathrm{K}, \mathrm{McNeill} \mathrm{A}$, et al. Changes in the prevalence of vaping and smoking among youth in Canada, England and the United States: Repeat national cross-sectional surveys. Br Med J. 2019;365: 12219. Available from: https://doi.org/10.1136/ bmj.I2219.

10. Arrazola RA, Dube SR, King BA. Tobacco product 
use among middle and high school students - United States, 2011 and 2012. MMWR Morb Mortal Wkly Rep. 2013; 62: 893-7.

11. Gentzke AS, Creamer M, Cullen KA, Ambrose BK, Willis G, Jamal A, et al. Vital signs: tobacco product use among middle and high school students - United States, 2011-2018. MMWR Morb Mortal Wkly Rep. 2019; 68:157164. Available from: https://dx.doi.org/10.15585\%2Fmmwr. mm6806e1.

12. Cullen KA, Ambrose BK, Gentzke AS, Apelberg BJ, Jamal A, King BA. Notes from the field: use of electronic cigarettes and any tobacco product among middle and high school students - United States, 2011-2018. MMWR Morb Mortal Wkly Rep 2018; 67:1276-7. Available from: http:// dx.doi.org/10.15585/mmwr.mm6745a5.

13. Cullen KA, Gentzke AS, Sawdey MD, Chang JT, Anic GM, Wang TW, et al. E-cigarette use among youth in the United States, 2019. JAMA. 2019; 322(21): 2095-103. Available from: doi:10.1001/jama.2019.18387.

14. Wang TW, Gentzke AS, Creamer MR, Cullen KA, Holder-Hayes E, Sawdey MD, et al. Tobacco product use and associated factors among middle and high school students - United States, 2019. Morb Mortal Wkly Rep. 2019;68(SS-12): 1-22. Available from: DOI: http://dx.doi. org/10.15585/mmwr.ss6812a1 [accessed 2019 Dec 6].

15. Gentzke AS, Creamer M, Cullen KA, Ambrose BK, Willis G, Jamal A, et al. Tobacco product use among middle and high school students-united states, 2011-2018. Morb Mortal Wkl Rep. 2018;67: 629-33.

16. Reid JL, Hammond D, Tariq U, Burkhalter R, Rynard VL, Douglas O. Tobacco Use in Canada: Patterns and Trends, 2019 Edition. Waterloo, ON: Propel Centre for Population Health Impact, University of Waterloo. [Electronic resource]. Available from: https://uwaterloo.ca/tobacco-usecanada/tobacco-use-canada-patterns-and-trends.

17. Laverty AA, Filippidis FT, Vardavas Cl. Patterns, trends and determinants of e-cigarette use in 28 European Union Member States 2014-2017. Prev Med. 2018;116: 13-8. Available from: https://doi.org/10.1016/j. ypmed.2018.08.028.

18. McNeill A, Brose LS, Calder R, Bauld L, Robson D. Evidence Review of E-cigarettes and heated tobacco products 2018; a report commissioned by public health England; Public Health England: London, UK, 2018 [(accessed 10 April 2019)]; [Electronic resource]. - Available from: https://www.gov.uk/government/publications/ecigarettes-and-heated-tobacco-products-evidence-review/ evidence-review-of-e-cigarettes-and-heated-tobaccoproducts-2018-executive-summary.

19. McNeill A, Brose LS, Calder R, Bauld L \& Robson D (2019). Vaping in England, an evidence updates, February 2019. A report commissioned by Public Health England. London: Public Health England [Electronic resource]. Available from: https://assets.publishing.service.gov.uk/ government/uploads/system/uploads/attachment_data/ file/821179/Vaping_in_England_an_evidence_update_ February_2019.pdf.

20. Smith DM, Gawron M, Balwicki L, Sobczak A, Matynia M, Goniewicz ML. Exclusive versus dual use of tobacco and electronic cigarettes among adolescents in Poland, 2010-2016. Addict Behav. 2019;90: 341-8. Available from: DOI 10.1016/j.addbeh.2018.11.035.
21. Brożek G, Jankowski M, Zejda J, Jarosińska A, Idzik A, Bańka P. E-smoking among students of medicinefrequency, pattern and motivations. Adv. Respir. Med. 2017;85: 8-14. Available from: DOI:10.5603/ ARM.2017.0003.

22. Brożek GM, Jankowski M, Lawson JA, Shpakou A, Poznański M, Zielonka TM, et al. The prevalence of cigarette and e-cigarette smoking among students in central and eastern Europe - results of the YUPESS Study. Int J Environ Res Public Health. 2019;16: 2297. Available from: https://doi.org/10.3390/ijerph16132297.

23. Pinkas J, Kaleta D, Zgliczyński WS, Lusawa A, Wrześniewska-Wal I, Wierzba W, et al. The prevalence of tobacco and e-cigarette use in Poland: A 2019 Nationwide Cross-Sectional Survey. Int J Environ Res Public Health. 2019;16(23): 4820. Available from: https://doi.org/10.3390/ ijerph16234820.

24. U.S. e-cigarette regulations - 50 state review (2020) [Electronic resource]. Available from: https:// www. publichealthlawcenter.org/sites/default/files/Stateswith-Laws-Restricting-Youth-Access-to-ECigarettesMarch152020.pdf.

25. National Academies of Sciences, Engineering, and Medicine; Health and Medicine Division; Board on Population Health and Public Health Practice; Eaton DL, Kwan LY, Stratton K, et al., eds. Public Health Consequences of E-Cigarettes. Washington (DC): National Academies Press (US); January 23, 2018. Available from: https://doi. org/10.17226/24952.

26. US department of health and human services. e-cigarette use among youth and young adults: A report of the surgeon general. Atlanta, GA: US Department of Health and Human Services, CDC; 2016. [(accessed July 27, 2018)]; [Electronic resource]. Available from: https:// www.cdc.gov/tobacco/data_statistics/sgr/e-cigarettes/ pdfs/2016_sgr_entire_report_508.pdf.

27. Quick facts on the risks of e-cigarettes for kids, teens, and young adults centers for disease [Electronic resource]. Available from: https://www.cdc.gov/tobacco/ basic_information/e-cigarettes/Quick-Facts-on-the-Risksof-E-cigarettes-for-Kids-Teens-and-Young-Adults.html.

28. Cao DJ, Aldy K, Hsu S, McGetrick M, Verbeck G, De Silva I, et al. Review of health consequences of electronic cigarettes and the outbreak of electronic cigarette, or vaping, product use-associated lung injury. J Med Toxicol. 2020;16(3): 295-310. Available from: https:// doi.org/10.1007/s13181-020-00772-w.

29. Outbreak of lung injury associated with the use of e-cigarette, or vaping, products. Center for Disease Control and Prevention. 2019. [Electronic resource]. Available from: https://www.cdc.gov/tobacco/basic_information/ecigarettes/severe-lung-disease.html.

30. Siegel DA, Jatlaoui TC, Koumans EH, Kiernan EA, Layer M, Cates JE, et al. Update: interim guidance for health care providers evaluating and caring for patients with suspected e-cigarette, or vaping, product use associated lung injury - United States, October 2019. MMWR Morb Mortal Wkly Rep. 2019;68(41): 919-927. Available from: doi:10.15585/mmwr.mm6841e3

31. Deliwala S, Sundus S, Haykal T, Theophilus N, Bachuwa G. E-cigarette, or vaping, product use-associated lung injury (EVALI): acute lung illness within hours of switching 
from traditional to e-cigarettes. Cureus. 2020;12(4): e7513. Available from: DOI:10.7759/cureus.7513.

32. Layden JE, Ghinai I, Pray I, Kimball A, Layer M, Tenforde MW, et al. Pulmonary illness related to e-Cigarette use in illinois and wisconsin - final report. $\mathrm{N}$ Engl J Med. 2020;382(10): 903-16. Available from: doi:10.1056/ NEJMoa1911614.

33. Kalininskiy A, Bach CT, Nacca NE, Ginsberg G, Marraffa J, Navarette KA, et al. E-cigarette, or vaping, product use associated lung injury (EVALI): case series and diagnostic approach. Lancet Respir Med. 2019;7(12): 101726. Available from: DOI:10.1016/S2213-2600(19)30415-1.

34. Triantafyllou GA, Tiberio PJ, Zou RH, Lamberty PE, Lynch MJ, Kreit JW, et al. Vaping-associated acute lung injury: a case series. Am J Respir Crit Care Med. 2019;200(11): 1430-31. Available from: doi:10.1164/ rccm.201909-1809LE.

35. Blount BC, Karwowski MP, Shields PG, MorelEspinosa M, Valentin-Blasini L, Gardner M, et al. Vitamin $\mathrm{E}$ acetate in bronchoalveolar-lavage fluid associated with EVALI. N Engl J Med. 2020;382(8): 697-705. Available from: DOI:10.1056/NEJMoa1916433.

36. Qiu F, Liang C-L, Liu H, Zeng Y, Hou S, Huang S, et al. Impacts of cigarette smoking on immune responsiveness: Up and down or upside down? Oncotarget 2017;8(1): 26884. Available from: DOI:10.18632/oncotarget.13613.

37. Duffney PF, McCarthy CE, Nogales A, Thatcher TH, Martinez-Sobrido L, Phipps RP, et al. Cigarette smoke dampens antiviral signaling in small airway epithelial cells by disrupting TLR3 cleavage. Am J Physiol Lung Cell Mol Physiol. 2018;314(3): L505-13. Available from: DOI:10.1152/ ajplung.00406.2017.
38. Guan WJ, Ni ZY, Hu Y, Liang W, Ou C, He J, et al. Clinical characteristics of coronavirus disease 2019 in China. N Engl J Med. 2020;382: 1708-20. Available from: DOI:10.1056/NEJMoa2002032.

39. Ruszkiewicz JA, Zhang Z, Gonçalves FM, Tizabi Y, Zelikoff JT, Aschner M. Neurotoxicity of e-cigarettes. Food Chem Toxicol. 2020; 138: 111245. Available from: DOI:10.1016/j.fct.2020.111245

40. Selekman, J. Vaping: It's all a smokescreen. Pediatric Nursing. 2019;45(1): 12-15,35.

41. Tobore TO. On the potential harmful effects of e-cigarettes (EC) on the developing brain: The relationship between vaping-induced oxidative stress and adolescent/ young adults social maladjustment. J Adolesc. 2019; 76:2029. Available from: DOI: 10.1016/j.adolescence.2019.09.004.

42. Kowitt SD, Osman A, Meernik C, Zarkin GA, Ranney LM, Martin J. Vaping cannabis among adolescents: prevalence and associations with tobacco use from a crosssectional study in the USA. BMJ. 2019;9(6): e028535. DOI:10.1136/bmjopen-2018-028535.

43. Volkow ND, Baler RD, Compton WM, Weiss SRB. Adverse health effects of marijuana use. N Engl J Med. 2014;370(23): 2219-27. DOI:10.1056/NEJMra1402309.

44. Meruelo AD, Castro N, Cota Cl, Tapert SF. Cannabis and alcohol use, and the developing brain. Behav Brain Res. 2017;325(PtA): 44-50. DOI: 10.1016/j.bbr.2017.02.025.

45. Silins E, Horwood LJ, Patton GC. Young adult sequelae of adolescent cannabis use: An integrative analysis. The Lancet Psychiatry. 2014;1(4): 286-93. DOI:10.1016/s2215-0366(14)70307-4.

46. Mamenko M, Romankevych I, Rakovska L, Lapii F, Katilov $\mathrm{O}$. Concerning about the potential hazards of using of electronic cigarettes to children and adolescents. Modern Pediatrics. Ukraine. 2019;8(104): 6-8. Ukrainian. 